\title{
Interest Groups and Government Spending in Italy, 1876-1913
}

\author{
NADIA FIORINO \\ ROBERTO RICCIUTI
}

CESIFO WORKING PAPER No. 2722

CAtegory 2: Public Choice

JULY 2009
An electronic version of the paper may be downloaded
- from the SSRN website: Www.SSRN.com
- from the RePEc website: Www.RePEc.org
- from the CESifo website: www.CESifo-group.org/wp




\title{
Interest Groups and Government Spending in Italy, 1876-1913
}

\begin{abstract}
In the last two decades of the XIX century Italy became an industrial country. Historians maintain that this process was affected by the action of some interest groups that pursued both state protection from competition and specific public expenditure programs. Starting from the economic literature of interest groups, this paper attempts to empirically investigate the role of the interest groups in public expenditure decisions in Italy from 1876 to 1913 . We argue that a proper indicator of the role of interest groups is their output. The analysis suggests that government spending was sensitive to the preferences of heavy industry rather then those of textile and cereal cultivators. We therefore highlight the role of the political process in setting economic policy at the early stages of Italian development.
\end{abstract}

JEL Code: H11, N43.

Keywords: special interest groups, public expenditure, Italian economic history.

Nadia Fiorino

University of L'Aquila

Faculty of Economics

67040 Roio Poggio

Italy

nadia.fiorino@univaq.it
Roberto Ricciuti

University of Florence

Department of Economics

Via delle Pandette 21

50127 Florence

Italy

roberto.ricciuti@unifi.it 


\section{Introduction}

In the last two decades of the XIX century, Italy experienced a change in its political system, and simultaneously became an industrial country. The law on tariff barriers to international trade passed on July 14, 1887 represents a key event of this process, by protecting grain, textile, sugar and steel industries. The Italian tariff was part of generalised protectionism in Europe, Austria-Hungary in 1882, Germany in 1879 and France in 1881 followed similar policies. In the late XIX century only England, the Netherlands and Belgium carried on the free trade policy in Europe. The 1887 tariff originated from landed interests concerned about falling grain prices resulting from American and Russian competition in the context of rapidly declining transportation costs. As the landed interests did not carry sufficient lobbying power a quid pro quo was negotiated with both textile and heavy industry for mutual support in Parliament for the respective demand for protection. ${ }^{1}$

Economic historians for a long time have discussed the necessity of the protectionist trade policy choice in Europe and in Italy in the late XIX century. Most historians' contributions agree that only a protectionist trade policy would have allowed a solid industrialisation to European late comers. With respect to the Italian case, Zamagni (1993) and Pescosolido (1998) followed this line of reasoning. Applying an infant industry argument, they maintained that without protection Italian industry would have not been able to survive foreign competition and Italy would not have developed. Federico and O'Rourke (1999) found that removal of trade barriers would have had small welfare and income distribution effects.

Scholars also have emphasised that the protectionist choice in Italy was driven by the action of specific interest groups. Gerschenkron highlighted that public intervention and more generally the activist state policy was appropriate in the situation of the new Kingdom.

\footnotetext{
${ }^{1}$ The law passed with 199 'yes' and 27 'no'. Toniolo (1990) described the 'horse trading' that took place among parliamentarians interested in helping specific firms in their constituencies.
} 
Nevertheless, he argued that this policy was devoted to economically unproductive projects, such as the promotion of the steel industry in Terni in 1884 and the subsidisation of the shipbuilding and naval industry between 1885 and 1896 (Gerschenkron, 1962). Fenoaltea (1978) condemned the choice of protecting the heavy industry because it strongly penalised the mechanical industry due to the higher costs of iron and steel. Federico and Tena (1998, 1999) have computed effective protection rates showing that some groups were strongly protected and others were not, without any coherence across sectors. They conclude that the lobbying activity of some interest groups was more effective than the activity of other groups in capturing politicians. ${ }^{2}$ The key element these analyses share is that some interest groups affected the mechanisms of capital formation, pursuing both protection from the competition and specific public spending programs (Bonelli, 1975, 1978; Capone, 1981).

A formal analysis of this hypothesis has yet to be carried out. So far the studies that have been developed do not go beyond descriptive statistics to motivate their arguments and do not provide any formal test. ${ }^{3}$ Data limitations partly explain the absence of more rigorous inquiries on this issue.

This paper builds on this line of reasoning: according to the public choice theory of government, we empirically examine the role the groups protected by the 1887 trade law exerted upon the expenditure decision-making process. We do not attempt to explain the economic and political determinants of the trade policy or relate revenues raised by tariffs with government spending. Rather, we use the protectionist trade policy of 1887 to identify the groups that emerged as interest groups and investigate the impact (pressure) of those groups on the size and the scope of the public sector from 1876 to 1913 . We do so by

\footnotetext{
${ }^{2}$ Fenoaltea (2006) provides an opinionated review of the issue.

${ }^{3}$ Brosio and Marchese $(1986$; 1988) built a model of demand in which the expenditure level is chosen by a median voter that belongs to an élite. They tested such a model for the time span 1861-1914. Fratianni and Spinelli (1982) focus on the determinants of public sector growth from 1861 to 1979 using a model of specialised groups.
} 
applying the interest group theory as a formal positive economic analysis of government behaviour as developed in the public choice literature. The starting point of the public choice view in analysing the role of the interest groups in policy formation is the fundamental importance of the rational maximising behaviour of private actors, and of politicians and bureaucrats as well. Individual incentives, the prospect of personal gain and loss motivate public sector actors, just as they do those in the private sector. Thus, governmental policies follow from the decision taken by self-interest individuals (politicians and bureaucrats) within the government organisation. The central aspect of public choice interest group theory concerns the nexus between politicians and voters (interest groups). Such a nexus can be stated more or less in conventional demand and supply terms (McCormick and Tollison, 1981). On the one hand, interest groups maximise their utility functions by demanding certain policies (transfer, public goods, regulation). On the other hand, individual policy makers maximise the probability of winning elections and offer pieces of legislation. Thus, elected officials act as brokers among competing interest groups pairing demanders and suppliers of regulation, as well as legislatures are the place "to clear the market for wealth transfers" (Shughart and Tollison, 1986). An important insight of interest group models is that the effectiveness of group lobbying activities is inversely related to its size, due to the heterogeneity of its memberships and goals (Olson, 1965).

As a positive theory of government, the interest group theory has been applied and explains a large variety of historical and contemporaneous governmental activities (Ekelund and Tollison, 1997), the government impact on income distribution (Congleton and Shugart, 1990), economic growth (Olson, 1982), and the activity of an individual legislator (Bronars and Lott, 1994). Yet, the main focus of the literature of interest groups has been the growth of government (McCormick and Tollison, 1981; Olson, 1982; Mueller and Murrel, 1986; Shugart and Tollison, 1986). These models, by emphasising the voting process within the 
legislature and the competition among different interest groups, predict a potential positive impact of interest groups seeking wealth transfers through the political process on the level of government, however measured (e.g., spending, regulation and so on).

The rest of the paper is organised as follows: section 2 frames the historical and political background. The model is specified in section 3 and tested in section 4 . The last section concludes.

\section{Identifying interest groups: the historical background}

In order to place our analysis in a historic perspective, this section provides an illustration of some historical events that motivate the empirical relationship we identify and show the key role of the interest groups in shaping public policy.

In 1861 the Kingdom of Piedmont became the Kingdom of Italy. After that, most of the effort was finalised to enforce a homogeneous set of rules throughout the national territory and to build an economy able to compete with the more advanced European countries. In 1876 the Right (Destra Storica) was defeated and the Left (Sinistra Storica) came into power. These changes in government produced at last two distinctive processes. First, the state became a financial institution that, by means of public debt and receipts, redistributed some of the resources generated in agriculture to other sectors of the economy (Aquarone, 1981). Second, the political equilibrium based on the interests of landowners and traders came to an end. These processes were closely linked. On the one hand, the state had a prominent role in the accumulation of capital. The modernisation of the economy started during the last ruling years as the Right became effective. Inflows of foreign capital were favoured by the abolition of the inconvertibility of the currency and by monetary stabilisation. A large government expenditure program was set to give the opportunity of new industrial investments. In order to increase the stock of fixed social capital and to support the steel-mechanical industry, 
privileges to Italian firms for railway works were accorded through the so-called Baccarini Law in 1882 and, indirectly, through the nationalisation of the railways by the establishment of the company Ferrovie dello Stato (National Railways Company) in 1905. This company gave procurements to the national industry by updating the rolling-stock. Furthermore, between 1885 and 1896, a program of subsidisation of the shipbuilding and naval industry was promoted. Between 1885 and 1913 the national naval industry received an average of 22 million liras per year (Zamagni, 1993). In 1884 a complete iron mill was created in Terni with public funds.

Overall government spending experienced a rapid growth throughout our sample. Simultaneously, changes in the composition of government budget took place; in particular spending on public services, such as transport, communication and construction and, later, spending on provision of public goods, such as education, increased (Brosio and Marchese, 1986; Aidt et al., 2006). On the other hand, this "new" role of the state, together with the agricultural crisis due to the competition from overseas and the failure of the capitalistic development in agriculture changed both the economic and the political weight of the primary sector. Starting from the 1880 s until World War I, the political system was characterised by the alliance between new entrepreneurial groups, mostly related with the heavy industry, and the traditional landowners of the South (Candeloro, 1970; Capone, 1981).

The effects on public policy of the consolidation of the alliance between traditional landowners and a more dynamic bourgeoisie appears more evident when we take into account two institutional issues that resulted in the electoral reform enacted in 1882. The reform extended the franchise for male voters, lowered the minimum voting age from 25 to 21 years and required as the essential condition capacity instead of socio-economic status. Meanwhile, status was considered an alternative to the accomplishment of the second year of primary school and was reduced from 40 to 19.80 liras. The gradual lifting of socio-economic 
restrictions on voting franchise strongly enlarged the constituency. In 1880 voters counted for $2.2 \%$ of the population of the Kingdom, while in 1882 they increased to $6.9 \%$ (Caracciolo, 1977). The reform law also modified the electoral regulations. Beginning from 1882 the district size was broadened and the single-member districts replaced with a system of competing lists to favour competition between political-ideological groups.

The second important institutional factor derives from the social composition of the Left. The change in power from the Right to the Left was more sociological than ideological. In fact, the Left kept a substantial continuity with previous policies. However, the Left was not homogeneous in bringing together landowners, new financial aristocracy, speculators, urban professionals and new entrepreneurs (Farneti, 1971). The electoral reform of 1882 was the result of the heterogeneous political composition of the élites and, at the same time, emphasised such heterogeneity by modifying both the constituency size and electoral districts.

\section{The empirical model}

Starting from the literature on interest groups, this section empirically estimates the influence of the interest groups on public expenditure programs between 1876 and 1913. The dependent variable of the model is the deviation of real total government expenditure from its trend value (DEVEXP). Our choice to use a) an aggregate measure of public spending, rather than particular expenditure areas, and b) the deviation of this measure from its trend deserves some discussion. Many empirical studies are concerned with narrow policy areas as they evaluate the success or failure of an interest group in influencing policy in one particular area. However, also non-voting activities like making up the details of the laws, lobbying among representatives, formulating amendments and so on, are crucial in determining legislative outcomes. In addition, the effect of lobbying is incremental and not only redistributive with respect to government spending: once some specific spending program has been captured by 
an interest group it is easier - for politicians - to add another one in order to help another group instead of shifting resources from one group to the other. Some sectors directly benefit from government spending via procurements. Among those considered here, iron and steel are the most important, since governments buy military equipment. However, government spending may indirectly benefit other sectors: agriculture from public investments in irrigation, for example; other areas of business from capital transfers to build new factories, and so on. Based on these arguments, we prefer to use an aggregate policy outcome like total government expenditure, rather than to analyse particular functions of public expenditure.

There are a number of reasons to choose the deviation from the trend of real total government expenditure. First, the Italian budget referred to fiscal years and was approved (roughly) in the spring. Thus, for example, the figure for 1901 would represent the average of expenditures for 1900-01 (decided in Spring 1900) and 1901-02 (approved in Spring 1901). It is implausible that governments and industry lobbyists were influenced by a prediction of 1901 output in making their decisions at budget time in Spring 1900 and Spring 1901. The whole decision-making process was drawn out over many years. Second, government spending is also determined by new "needs" (i.e., schooling), that are partially a function of time, therefore we want to remove them from the outcome of the lobbying activity. The variable is obtained by applying the Hodrick-Prescott Filter, with $\lambda=100$ as suggested by Hodrick and Prescott for annual data. ${ }^{4}$

The main problem of empirical analyses in the field of interest groups is related to the identification of a proxy for the special group. In order to capture the pressure of the interest

\footnotetext{
${ }^{4}$ We interpret the Hodrick-Prescott Filter as a device to obtain an estimate of the trend without an economic meaning in this context. The Filter includes the value at $\mathrm{t}+1$ of the variable, and for the reasons outlined above this would imply a very forward-looking behaviour from interests groups and politicians. We have also estimated long-run government spending through a 3-year moving average, and results for deviation of government spending obtained in this way are similar to those presented here. They are available upon request from the authors.
} 
groups in shaping public policy, some models focus on their political activities, such as the campaign contributions (Crain and Tollison, 1977) and the lobbying activity in the legislative and executive branches of government (McCornik and Tollison, 1981). As the data on interest groups activity are sometimes not available, some contributions use the structural characteristics of the groups. Gardner (1987) employs the average size of the producers and the percentage of owners' income. Mueller and Murrell (1986) and McCallum and Blais (1987) estimate the strength of interest groups by the number of special interest organisations. To measure ideological groups and labour unions that are formally organised, Kischgassner and Pommerehne (1988) use the number or the percentage of members. When the interest group is not formally organised and membership data are unavailable, indirect ex ante proxies, such as the number of producers in an industry (Guttman, 1978; Miller, 1991) or some measures of concentration, are applied. Yet in this case, while the results in support of the influence of the interest groups in public policy formation are not robust; the relationship between numbers and influence might be non-monotonic and might be dependent on the type of interest group.

We use the law enacted in 1887 as an instrument to detect the special interest groups that acted as "pressure groups" on the public decision-making process. By means of duties and tariffs such a law protected from international competition the entrepreneurs of textile, sugar, steel and grains. All of them are considered in our analysis as the interest groups that affected government expenditure programs. One may wonder that the political decisions which the 1887 law reflects were not the outcome of a coherent vision for supporting certain industries instead of others. Nevertheless, the relationship between public expenditure and the interest groups that benefited from the protectionist law seems historically correct and analytically sustainable. Some of the mechanisms implemented in 1887 (in particular, the willingness of the political system to compromise with interest groups) kept in place for a 
long time (Bonelli, 1978; Aquarone, 1981).

Some models (e.g., Mueller and Murrel, 1986) measure interest groups using either the number of special interest organisations in a country or the number of the members of each group. This kind of proxies has the advantage of solving the free-riding problems that, as Olson's (1965) influential theoretical study highlighted, may arise from the increase in the group size. Because of the lack of data, it is impossible to replicate this procedure. Even so, the use of the number of the workers is an unsatisfactory way to measure and compare the interest group influence in our sample because the groups we identify present quite a different capital/labour ratio. For this reason, we cannot exclude a priori that a sector may have relatively few members due to a more intensive use of capital, but which may exert a large impact on public decision-making process.

On the one hand, one may argue that an index of concentration would be a more appropriate measure. The degree of concentration, as well as the membership, allows alleviating the collective action problems (free-riding). However, the relationship between the independent variable and the proxies like the membership or the degree of concentration is not only driven by free-riding effects but also by effects which relate to the "political strength" of an interest group. In our sample textile and grain productions are fragmented in a wide number of medium and small sized enterprises; further, in all of the industries we have analysed importers co-exist with exporters, then different goals subsist within the same industry. Nevertheless, we do not know the internal organisation of the group, for instance, whether the interests of some members enterprises of an industry are pivotal with respect to the interests of some other members of the same group, or if a larger group (with a larger freeriding problem) has more electoral resources. In other words, the relationship between number and influence is not a linear one, and perhaps not even a monotonic one. Based on the Olson argument and considering the internal organisation of the industries we have analysed, 
an index of concentration might underestimate or overestimate the strength of the interest group as a pressure group.

These considerations, together with the unavailability of suitable alternative data, have driven us to measure the identified groups through the gross saleable output of cereals $(C E R)$ and the value added of the textile (TEX) and the iron and steel industries (ISI). ${ }^{5}$ As disaggregated data do not exist for the sugar industry, we are not able to construct the related interest group proxy. ${ }^{6}$

The measures we propose make it possible to compare the strength of the different entrepreneurs in shaping government expenditure. Furthermore, as we emphasise the importance of the special interest groups in adding further expenditure items to the public budget, our proxies give a good approximation of the income that these industries produced and then of the wealth transfers that policy makers caused through redistribution and public expenditure ${ }^{7}$. The basic hypothesis is that the size of government is positively related to the strength of the interest groups; thus, CER, TEX and ISI are expected to be positive. ${ }^{8}$

The traditional role of the government views it as a provider of public goods. We

\footnotetext{
${ }^{5}$ Putting iron and steel industries together with engineering is maybe questionable since, according to Gershenkron (1962), the latter was penalised by the protection of the former. However, Toniolo $(1977,1990)$ claims that this is not the case.

${ }^{6}$ The use of sugar sale tax revenue to measure the product of the sugar industry (or for all industries) is impossible given the large number of missing data in Istat (1958).

${ }^{7}$ Kamath (1989) also uses income variables to capture the "political success" of the interest groups in shaping public policy.

${ }^{8}$ A possible alternative to value added are tariff rates, but they are extremely difficult to calculate. First, they differed among each group (for example, for cottons we need to distinguish between several subgroups: raw cotton includes carded cotton, cotton wool, and cotton waste; among cloth we distinguish between standard grey, bleached, dyed and printed cloth; other cotton products include other cotton products (embroidered and brocaded cloth, muslin, tulle, velvet, knits, ribbons, trimmings. A third group covers mixed textiles (Fenoaltea, 2001; 2003). Second, they were frequently revised. Third, importers were often able to bypass statutory rates. Another unsuitable alternative is the revenue from imported goods: a very successful tariff would make imports equal to zero, therefore providing no revenue.
} 
consider this issue by including the variable $P O P$, which is the size of the total population (Istat, 1957). We expect POP to be positive, since demand for public goods grows as long as population increases. Finally, we take into consideration changes in the institutional, political and legislative environment that occurred along the transition from a restrictive electoral system to its extension in 1882 . The number of people with the right to vote is given by the variable VOT (Istat, 1958). Basic economic principles suggest that the extension of franchise should be associated with some expansion of the public sector, in particular in cases where democratically elected governments become accountable to poorer voters (Meltzer and Richard, 1981). On the basis of these arguments we expect VOT to be positive. Finally, we include per capita GDP (GDPpc) because, according to the Wagner Law, as a society becomes richer, there is an increasing demand for public expenditure.

The basic model used to describe expenditure decision making process is the following:

$$
D E V E X P_{\mathrm{t}}=\alpha_{1+} \alpha_{2} G D P p c_{\mathrm{t}}+\alpha_{3} C E R_{\mathrm{t}}+\alpha_{4} T E X_{\mathrm{t}}+\alpha_{5} I S I_{\mathrm{t}}+\alpha_{6} P O P_{\mathrm{t}}+\alpha_{7} V O T_{\mathrm{t}}+\varepsilon_{\tau}
$$

where $\varepsilon_{\tau}$ is a random error. Some variables may be endogenous: for example, as argued before in the light of the interest groups theory, ISI affects DEVEXP, but higher government spending may increase the output of steel and iron, because of procurement and demand effects. For these reasons we address reverse causation applying the Two Stage Least Squares (2SLS) technique by taking two lags of ISI as instruments. Figures 1 shows the behaviour over time of population and voters, figures 2 and 3 plot government spending and deviation of government spending from trend, respectively.

[Figures 1 and 2 about here] 
Data for the dependent variable is taken from Federico (2008), it is constructed using data from Ragioneria Generale dello Stato (1969) and expressed at 1911 prices. Most of the state budget consisted in payment of interests on public debt and military expenditure (mainly for personnel). The gross sellable output of cereals is provided by Federico. In a number of works he has reconstructed the statistical data for agriculture, showing that previous estimates from Istat (1957) overestimated grain production in the early 1870s and underestimated agricultural production from the 1880s until World War I. Federico (2000) reports the value added and gross sellable output data for benchmarks in 1891, 1911, 1938 and 1951, divided for the most important products. ${ }^{9}$ In a subsequent paper (Federico, 2003) he gives the gross sellable output for the whole agricultural production from 1861 to 1913 . Our data (which should be considered preliminary), directly provided by Giovanni Federico, gives the gross sellable output of cereals, which we take as a proxy for grain production. TEX, ISI and per capita GDP are taken from the new estimates of Italian industrial production given by Fenoaltea (2005). All production data are in 1911 prices.

\section{Empirical results}

\subsection{Tests for nonstationarity}

Before estimating the structural equation, the analysis of the stochastic properties of the series is applied in order to establish whether public expenditure and all explanatory

\footnotetext{
${ }^{9}$ The gross sellable output is the value of all products minus their reinvestment in the agricultural sector. The value added is obtained from the gross sellable output by subtracting the cost of expenditures from other sectors of the economy. For the years 1891 and 1911 the expenditure to gross sellable output ratio was equal to $4.3 \%$ and $7.09 \%$, respectively. Clearly, the choice of putting together different measures of production adds some noise in the estimations. However, we believe that this is not sizable, and removing expenditure based on the benchmark years from all years would have added further noise, since we would have made assumptions on the distributions over time of expenditures that would not be soundly based.
} 
variables used in the regression model share a long or a short run relationship. This information makes it possible to correctly specify the model by avoiding spurious regression problems. The stationarity has been verified by the Augmented Dickey-Fuller tests (ADF), and the autoregressive structure has been determined according the Schwarz Information Criterion (SIC). The test specification includes a constant and a trend for all series. The results are presented in Table 1: nonstationarity can never be rejected. ${ }^{10}$

[Table 1 about here]

\subsection{Regression results}

The assessment of the stochastic properties of the series allows us to express equation (1) by first differencing all the variables in order to prevent spurious regression. Therefore, the estimated regressions are short-term relations. From an econometric point of view the specification test cannot reject the validity of the instruments, and the variables are jointly different from zero at the usual significance levels.

[Table 2 about here]

The variable CER is not significantly different from zero. The class of grain cultivators mainly represented elderly landowners. They were not interested in the capitalistic development of agriculture; rather they operated in order to keep their property rights and to crystallise social and productive relationships. ${ }^{11}$ Therefore, it is reasonable to maintain that

\footnotetext{
${ }^{10}$ The variable GDPpc is I(1) since the ADF test rejects the null of nonstationarity on the first-differenced series (the test statistics is -4.1192 , with 1 lag according to the SIC).

${ }^{11}$ Most likely, the interest of the grain entrepreneurs in the infrastructures, such as ports for sea-transportation, would grow stronger during World War I.
} 
they controlled more on the receipts side of the budget, rather than on expenditure. Indeed, between 1885 and 1910 the estate tax decreased from 125 to 84 million liras (Castronovo, 1975, p. 143). Nevertheless, the requests of the traditional landowners were focused on the tariff of wheat that scholars (Toniolo, 1978, among others) consider the pactum sceleris the protected industrial sectors accepted to buy their privileges. ${ }^{12}$

The coefficient of ISI is significantly positive. Empirical evidence suggests the idea, maintained by historians, that the state helped the iron and steel industry through procurement both in the military and in the railway sectors (in particular after nationalisation in 1905). In addition, government grants supported the naval industry. Despite the fact that such industry was founded with the direct support of the state, this result emphasises that it was a private business. It was able to put pressure on the government to guarantee a satisfying utilisation of the productive capacity, overcoming the small size of the national market. The establishment of the Società degli Altoforni, Acciaierie e Fonderie di Terni in 1884 is the most evident sign of the role of the interest groups in the political framework and of logrolling within the legislature (Bonelli, 1975: 15). The firm, while remaining a private company, was the result of both the private capital led by V. S. Breda, who also was elected to the Senate, and the state capital: the government advanced 12 million liras to the company buying some components of military navies. Furthermore, the interest group of metal-makers also benefited from monetary and credit policy: Terni's iron mills avoided bankruptcy by receiving loans funded by the Bank of Italy (Bonelli, 1975; Cerioni, 2001).

The variable TEX is insignificant. The different behaviour of the textile and steel entrepreneurs emerged already from the Inchiesta Industriale, a document framed during the

\footnotetext{
12 Maffeo Pantaleoni (1901) in a speech at the Chamber of Deputies highlighted that the tariff on wheat: 1) solely rewarded the landowners (about 50,000 units) and harmed both the sharecroppers and the tenants waiting for relocation; 2) guaranteed to the landowners a return (150 million liras) higher than costs represented by the estate tax (107 million liras).
} 
last years of the government of the Left (1870-1874) and considered by the historians the most important source of information to reconstruct the origin of the protectionist choice realised in 1878 and $1887 . .^{13}$ The Atti dell'Inchiesta Industriale emphasised that textile and steel entrepreneurs demanded aid from the state, especially in the form of protectionist measures. However, while the textile entrepreneurs did not put such a request in a strategy oriented to a qualitative reinforcement of their firms, the steel entrepreneurs asked for public investments also in education to obtain a skilled labour force.

Population is positive and significantly different from zero. This result shows that an increase in population has the same effect on residual government expenditure. The variable for the extension of the franchise is insignificant, probably because the number of effective voters remained small. Indeed, during this period governments faced the so-called banditry (brigantaggio) in Southern Italy and the fasci siciliani, a separatist political movement in Sicily, which represented a way to express social discontent without going through the poorly representative institutional and political system. Finally, per capita GDP becomes significant when some insignificant variables are removed.

\section{Conclusions}

The trade tariffs imposed in 1878 and confirmed in 1887 are usually indicated as milestones of Italian policy in the $19^{\text {th }}$ century. It is reasonable to maintain that these political decisions were not the outcome of a careful and systematic attempt to set favourable conditions for the birth and the development of particular industries. However, historiography emphasises that these episodes were the result of positive answers to the requests of powerful interest groups. Such requests strengthened the alliance between political and entrepreneurial groups.

\footnotetext{
${ }^{13}$ See on this point Baglioni (1974) and Marongiu (1995, 311-312).
} 
Interest groups can seek several goals: protection from international competition and public expenditure programs, but also tax breaks and long-term contracts with government agencies. Starting from these considerations we have tested the influence that the groups protected in 1887 exerted on the expenditure decision-making process over 1876-1913. The main result points to the role of the iron and steel industries as the most powerful interest group.

This is in line with a traditional view dating back from the liberal school of the early $20^{\text {th }}$ century. Luigi Einaudi (and in the same line the "L'Unità" edited by Gaetano Salvemini) in a number of articles attacked those he sarcastically called the 'drillers'. Strictu sensu these were drilling in Northern Italy looking for oil, but in a more general way Einaudi referred to all entrepreneurs whose investment choices were distorted by government subsidies and tariffs. In particular, he showed the excessive production costs of the iron and steel industry and its behaviour as a trust were detrimental for the machine industry, the unreliability of the balance sheets of the companies, and quantified the total costs of the protection and subsidies of the iron and steel industry in 260 million liras in $1910 .^{14}$ In the view of the free-trade scholars the protectionist tariffs was a signal that policy makers were responsive to the requests of some interest groups (Cardini, 1981; Tedesco, 2002). Furthermore, Pantaleoni, de Viti de Marco and Mazzola used the "Giornale degli Economisti" to emphasise the relevance of the "heavy" industry interests to the understanding of political behaviour. The Agriculture Minister Bruno Chimirri was one of the most criticised by Mazzola for his defence of vested interests. Cardini (1981: 109) reported a statement in which Mr Chimirri described the intimate linkage between government spending and industries:

"There is nothing sadder for the economy than the smokestacks of the

\footnotetext{
${ }^{14}$ See, among others, Einaudi (1911a and 1911b; 1912), Einaudi and Riboni (1912).
} 
bankrupted factories in Savona, the heavy mallets of Terni for which we hear at every blow taxpayers groaning, the factories in Pozzuoli producing machines paid by Italians". (Our translation)

Probably none of these free-market economists could have said it better.

\section{Acknowledgements}

We thank Stefano Fenoaltea, Emma Galli and Gaetano Sabatini for useful comments, and Giovanni Federico for sharing his data and for comments. The usual caveat applies. 


\section{References}

Aidt, T.S., Dutta, J. and Loukoianova, E. (2006). Democracy comes to Europe: Franchise extension and fiscal outcomes 1830-1938, European Economic Review 50, 249-283.

Anderson, G.M, Tollison, R.D. (1985). Ideology, interest groups and the repeal of the Corn Laws, Journal of Institutional and Theoretical Economics 141, 197-212.

Aquarone, A. (1981). L'Italia Giolittiana (1896-1915). Bologna: Il Mulino.

Baglioni, G. (1974). L’Ideologia della Borghesia Industriale dell'Italia Liberale. Torino: Einaudi.

Becker, G. (1983). A theory of competition among pressure groups for political influence. Quarterly Journal of Economics 98, 371-400

Bonelli, F. (1978). Il Capitalismo Italiano. Linee Generali di Interpretazione. Annali di Storia d'Italia. Torino: Einaudi.

Bonelli, F. (1975). Lo Sviluppo di una Grande Impresa in Italia. La Terni dal 1884 al 1962. Torino: Einaudi.

Bronars S.G. and Lott, J.R. (1997). Do campaign donations alter how politicians vote?, Journal of Law and Economics 40, 317-350.

Brosio, G. and Marchese, C. (1988). The growth of government under different redistributive rules: A long term study of the Italian case, Public Finance Quarterly 16, 439-463.

Brosio, G. and Marchese, C. (1986). Il Potere di Spendere. Economia e Storia della Spesa Pubblica dall’Unificazione ad Oggi. Bologna: Il Mulino.

Candeloro, G. (1970). Storia dell'Italia Moderna. Milano: Feltrinelli.

Capone, A. (1981). Destra e Sinistra da Cavour a Crispi. Storia d'Italia. Vol. XX. Torino: UTET.

Caracciolo, A. (1977). Stato e Società Civile. Problemi dell’Unificazione Italiana. Torino: Einaudi.

Cardini, A. (1981). Stato Liberale e Protezionismo in Italia (1890-1900). Bologna: Il Mulino.

Castronovo, V. (1975). La Storia Economica. Torino: Einaudi.

Cerioni I., (2001). La Banca d'Italia e il consorzio siderurgico. Fonti per la storia della siderurgia in età giolittiana nelle carte dell'archivio della Banca d'Italia. Quaderni dell’Ufficio Ricerche Storiche della Banca d'Italia, 2.

Crain, W.M. and Tollison, R.D. (1977). The influence of representation on public policy, Journal of Legal Studies 6, 355-362.

Congleton, R. and Shugart II, W.F. (1990). The growth of social security: electoral push or electoral pull?, Economic Inquiry 28, 109-132. 
Einaudi, L. (1911a). I trivellatori di Stato, La Riforma Sociale 22, 1-14.

Einaudi, L. (1911b).Nuovi favori ai siderurgici?, La Riforma Sociale 22, 97-112.

Einaudi, L. (1912). I fasti italiani degli aspiranti trivellatori della Tripolitania, La Riforma Sociale, 23, 161-193.

Einaudi, L. and Riboni, P. (1912). Polemizzando con i siderurgici, La Riforma Sociale 23, 850-888.

Ekelund, R.B. and Tollison, R.D. (1997). Politicized Economies: Monarchy, Monopoly and Mercantilism. College Station: Texas A\&M University Press.

Farneti, P. (1971). Sistema Politico e Società Civile: Saggi di Teoria e Ricerca Politica. Torino: Giappichelli.

Federico, G. and Tena, A. (1998). Was Italy a protectionist country?, European Review of Economic History 2, 73-97.

Federico, G. and Tena, A. (1999). Did trade policy foster Italian industrialization? Evidence from effective protection rates 1870-1930, Research in Economic History 19, 111-130.

Federico, G. and O'Rourke, K. (1999). Much ado about nothing? The Italian trade policy in the 19th century, in: J. Williamson and Pamuk, S. (eds.) The Mediterranean Response to Globalisation before 1950, London: Routledge.

Federico, G. (2000). Una stima del valore aggiunto in agricoltura, in: G.M. Rey (ed.), I conti economici dell'Italia. 3.2 Il valore aggiunto per il 1891, 1938 e 1951, Bari: Laterza, 3112.

Federico, G. (2003). Le nuove stime della produzione agricola italiana, 1860-1910: primi risultati ed implicazioni, Rivista di Storia Economica 19, 359-381.

Federico, G. (2008). Always on the brink: Piedmont and Italy, mimeo.

Fenoaltea, S. (1978). Riflessioni sull'esperienza industriale italiana dal Risorgimento alla prima guerra mondiale, in: G. Toniolo (ed.), L'economia italiana 1861-1940, Bari: Laterza.

Fonoaltea, S. (2001). The growth of Italy's cotton industry, 1861-1913: A Statistical Reconstruction, Rivista di Storia Economica 17, 139-171.

Fenoaltea, S. (2003). Product Heterogeneity Trade and Protection: the Cotton Industry in Post-Unification Italy, In: Falchero, A.M., Giuntini, A., Nigro, G., and Segreto, L. (eds.) La Storia e l'Economia. Miscellanea di Studi in Onore di Giorgio Mori. Varese, Edizioni Lativa.

Fenoaltea, S. (2005). Notes on the rate of industrial growth in Italy, 1861-1913, Journal of 
Economic History 63, 695-735.

Fenoaltea, S. (2006). Il protezionismo e l'emigrazione, In: S. Fenoaltea, L'economia italiana dall'Unità alla Grande Guerra. Roma-Bari, Laterza.

Fratianni, M. and Spinelli, F. (1982). The growth of government in Italy: Evidence from 1861 to 1979 , Public Choice 39, 221-243.

Gardner, B.L. (1987). Causes of U.S. farm commodity programs, Journal of Political Economy 95, 290-310.

Gerschenkron, A. (1962). Economic Beckwardness in Historical Perspective. Cambridge MA: Harvard University Press.

Ghisalberti, C. (1986). Storia Costituzionale d'Italia 1848-1948. Bari: Laterza.

Guttman, J.M. (1978). Interest groups and the demand for agricultural research, Journal of Political Economy 86, 467-484.

ISTAT (1957). Annali di Statistica, Le Rilevazioni Statistiche in Italia dal 1861 al 1956. Serie VIII, vol. 8-9, Roma.

ISTAT (1958). Sommario di Statistiche Storiche Italiane, 1861-1955, Roma.

Kamath, S.J. (1989). Concealed takings: Capture and rent-seeking in the Indian sugar industry, Public Choice 62, 119-138.

Kirschgassner, G. and Pommerehne, W. (1988). Government spending in federal system: A comparison between Switzerland and Germany. In: J.A. Lybeck and M. Henrekson (eds.), Explaining the Growth of Government. Amsterdam: North Holland.

Marongiu, G. (1995). Storia del Fisco in Italia. La Politica Fiscale della Destra Storica (1861-1876). Torino: Einaudi.

McCallum, J. and Blais, A. (1987). Government, special interest groups and economic growth, Public Choice 54, 3-18.

McCornik, R.E. and Tollison, R.D. (1981). Politicians, Legislation and the Economy. Boston: Matinus Nijhoff.

Meltzer, A.H. and Richard, S.F. (1981). A rational theory of the size of government, Journal of Political Economy 89, 914-927.

Miller, T.C. (1991). Agricultural price policies and political interest groups competition, Journal of Policy Modelling 13, 489-513.

Mitchell, W.C. and Munger, M.C. (1991). Economic models of interest groups: an introductory survey, American Journal of Political Science 35, 512-546.

Mueller, D.C. and Murrel, P. (1986). Interest groups and the size of government size, Public Choice 48, 125-145. 
Olson, M. (1965). The Logic of Collective Action: Public Goods and the Theory of Groups, Cambridge, MA: Harvard University Press.

Olson, M. (1982). The Rise and Decline of Nations: Economic Growth, Stagflation and Social Rigidities. New Haven CT, Yale University Press.

Pantaleoni, M. (1901). Discorso pronunciato alla Camera dei Deputati, 20 marzo 1901, Atti parlamentari, Camera dei Deputati, Discussioni, XXI legislatura, I sessione.

Pescosolido, G. (1998). Unità Nazionale e Sviluppo Economico, Bari: Laterza.

Potters, J. and van Winden F. (1995). Models of interest groups: Four different approaches, in: Schofield (ed.) Social Choice and Political Economy. Boston, MA: Kluwer.

Potters, J. and Sloof, R. (1996). Interest groups: A survey of empirical models that try to assess their influence, European Journal of Political Economy 12, 403-442.

Ragioneria Generale dello Stato (1969). Il bilancio dello Stato italiano dal 1862 al 1967, Roma: Istituto Poligrafico dello Stato.

Shughart, W.F. and Tollison, R.D. (1986). The political economy of legislation and the growth of government, Research in Law and Economics 9, 111-127.

Tedesco, L. (2002). L'alternativa Liberista in Italia: Crisi di Fine Secolo, Antiprotezionismo e Finanza Democratica nei Liberali Radicali (1898-1904). Soveria Mannelli: Rubbettino.

Toniolo G. (1977). Effective protection and industrial growth: the case of Italian engineering, Journal of European Economic History 6, 659-673.

Toniolo G. (1978). Alcune tendenze dello sviluppo economico italiano 1861-1940, in: G. Toniolo (ed.), L'economia italiana 1861-1940, Bari: Laterza.

Toniolo G. (1990). An Economic History of Liberal Italy, 1850-1918. London: Routledge.

van Winden F. (1999). On the economic theory of interest groups: towards a group frame of reference in political economics, Public Choice 100, 1-29.

Zamagni, V. (1993). The Economic History of Italy 1860-1990. Oxford: Clarendon Press. 


\begin{tabular}{cccc}
\hline & ADF test statistics & Lags & Order of integration \\
\hline CER & -3.8184 & 3 & $\mathrm{I}(1)$ \\
DEVEXP & -2.3114 & 1 & $\mathrm{I}(1)$ \\
GDPpc & -0.1341 & 1 & $\mathrm{I}(1)$ \\
ISI & -2.1285 & 1 & $\mathrm{I}(1)$ \\
POP & -2.5931 & 2 & $\mathrm{I}(1)$ \\
TEX & -2.1872 & 6 & $\mathrm{I}(1)$ \\
VOT & -0.1595 & 1 & $\mathrm{I}(1)$ \\
\hline
\end{tabular}

All specifications include trend and intercept. Critical values at the $1 \%, 5 \%$ and $10 \%$ for the ADF tests with trend and intercept are $-3.96,-3.41$, and -3.13 , respectively. 
TABLE $2-2$ SLS results
(1)
(2)
(3)
(4)

\begin{tabular}{lcccc}
\hline Constant & $0.085^{* *}$ & $0.081^{* *}$ & $0.078^{* * *}$ & $0.064^{* * *}$ \\
dGDP & $(0.034)$ & $(0.031)$ & $(0.023)$ & $(0.017)$ \\
& 0.346 & 0.305 & $0.267^{* *}$ & $0.249^{* *}$ \\
dCER & $(0.903)$ & $(0.855)$ & $(0.092)$ & $(0.099)$ \\
& -0.077 & -0.079 & & \\
dTEX & $(0.187)$ & $(0.192)$ & & \\
dISI & -0.052 & & & \\
& $(0.374)$ & & & $0.087 * * *$ \\
dPOP & $0.244^{*}$ & $0.237^{* *}$ & $0.241^{* *}$ & $(0.014)$ \\
& $(0.129)$ & $(0.114)$ & $(0.116)$ & $0.889^{* * *}$ \\
dVOT & $0.891^{* *}$ & $0.916^{* *}$ & $0.808^{* *}$ & $(0.262)$ \\
& $(0.434)$ & $(0.378)$ & $(0.297)$ & \\
\hline N & 0.059 & 0.064 & & 36 \\
Specification test & $(0.047)$ & $(0.062)$ & & 2.2532 \\
Testing $\beta=0$ & 36 & 36 & 36 & $10.055^{* *}$ \\
\hline
\end{tabular}

The specification test is distributed under the null of the validity of the instruments as a $\chi^{2}$ with degrees of freedom equal to the number of instruments minus one. The test $\beta=0$ is distributed as a $\chi^{2}$ with degrees of freedom equal to the number of variables minus one. Heteroskedasticity consistent standard errors in parentheses. The operator $d$ indicates first differences. $* * *, * *$ and $*$ indicate significance at the $1 \%, 5 \%$ and $10 \%$ levels, respectively. 
Figure 1. Population and voters levels (1876-1913)

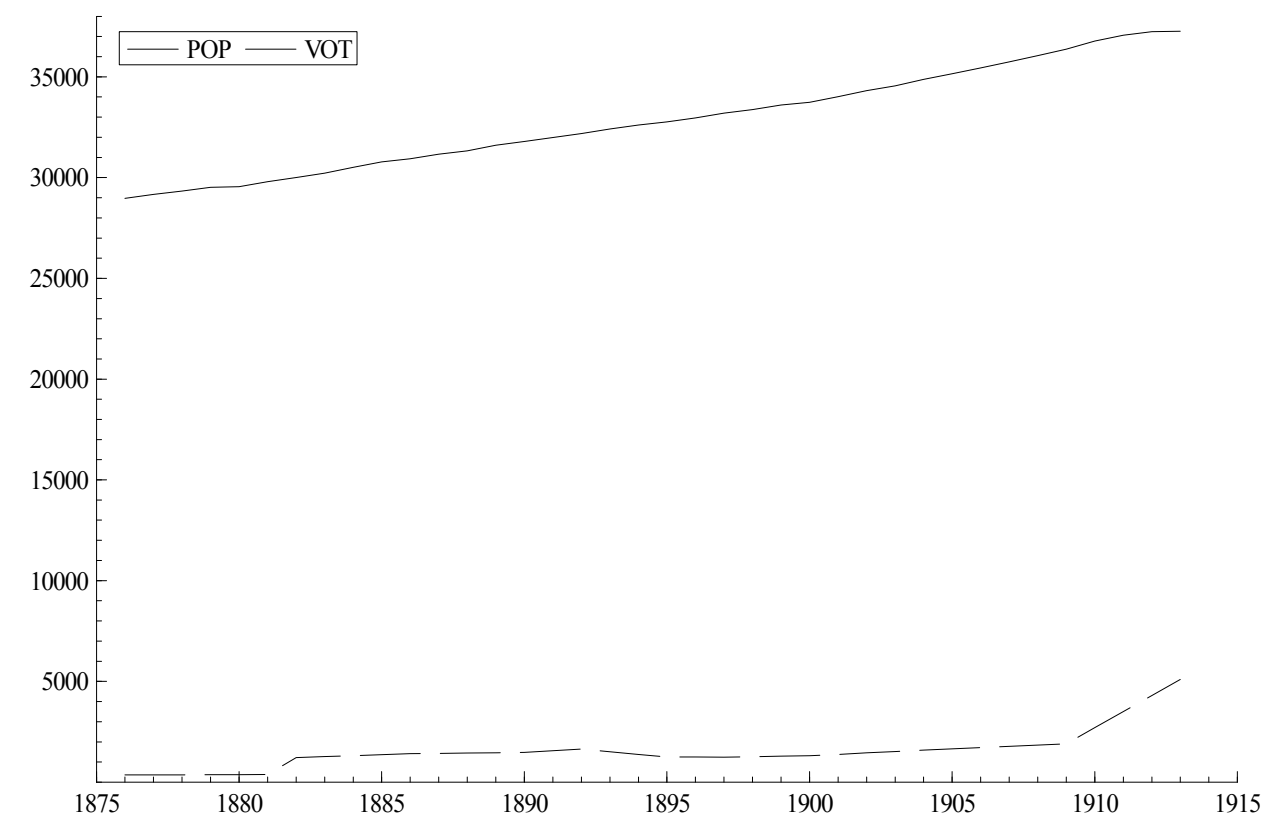


Figure 2. Real public expenditure 1876-1913 (million liras)

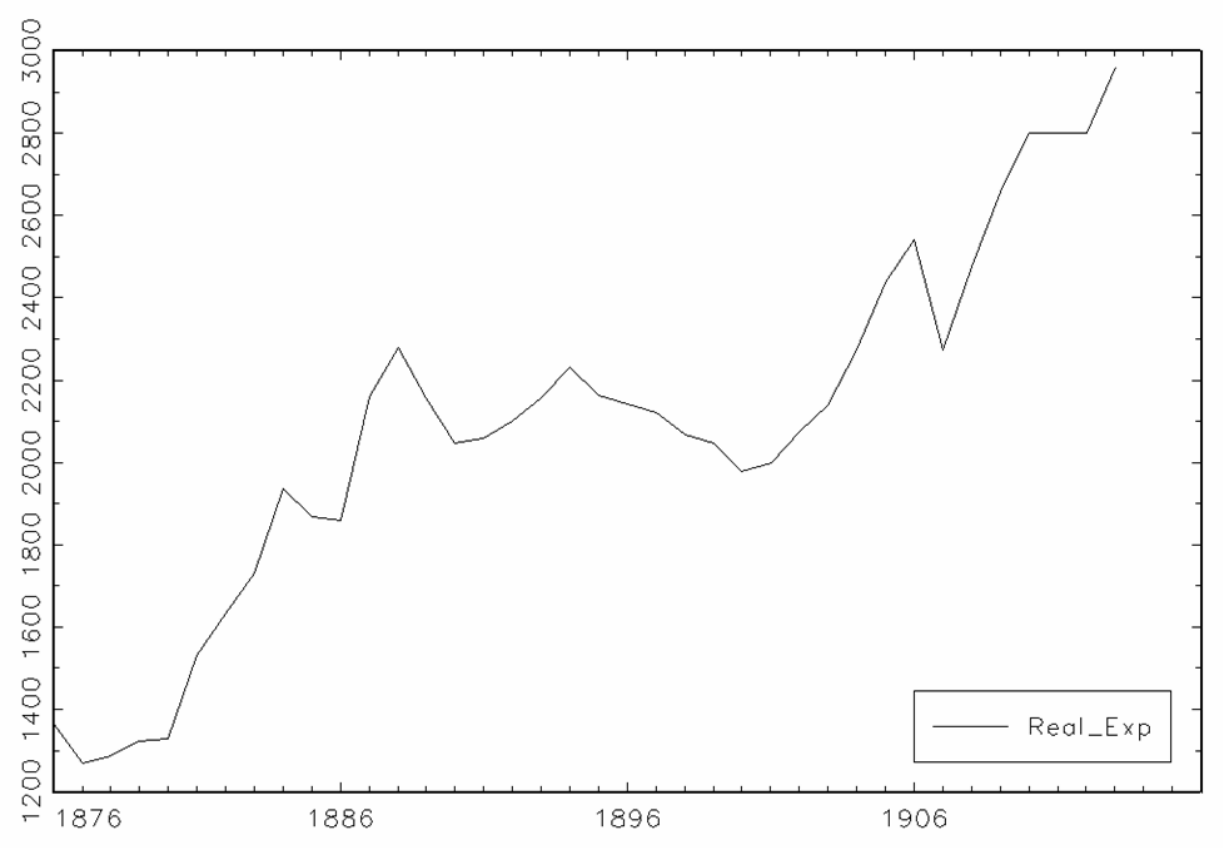


Figure 3. Deviation of real expenditure from trend (HP filtered)

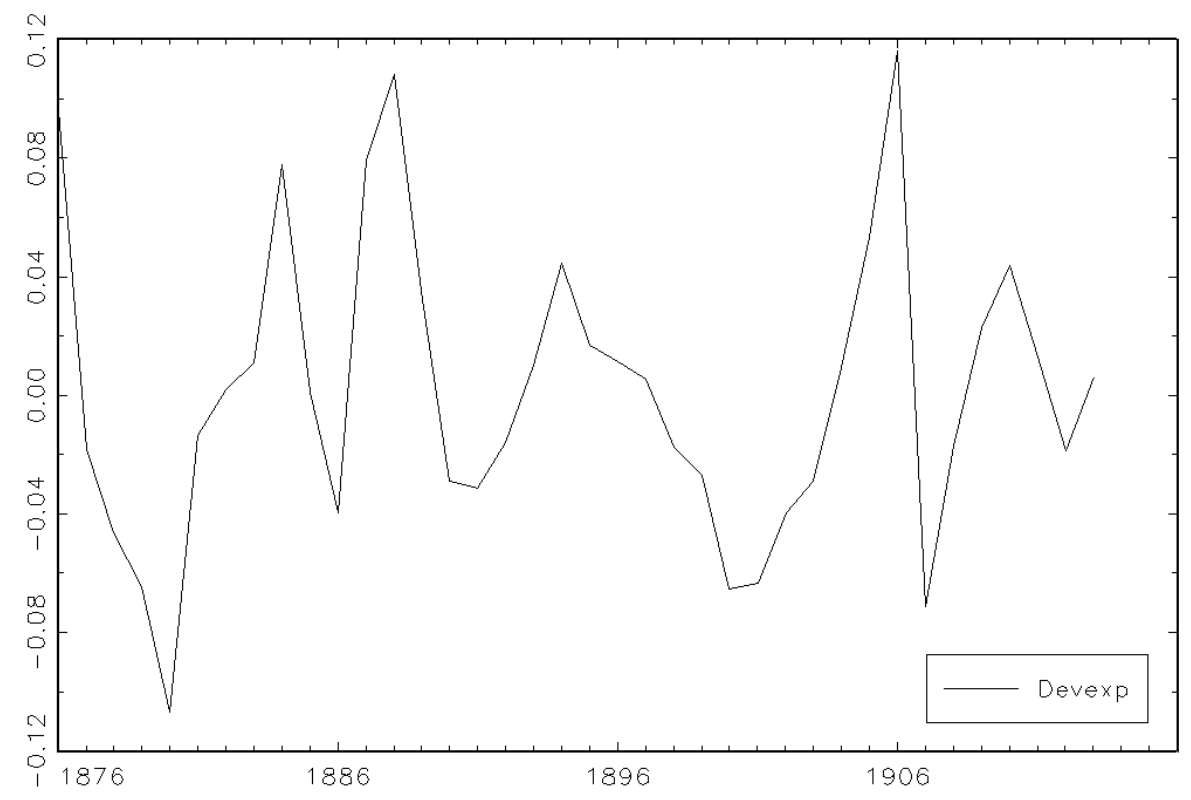




\section{CESifo Working Paper Series}

for full list see www.cesifo-group.org/wp

(address: Poschingerstr. 5, 81679 Munich, Germany, office@cesifo.de)

2657 Susanne Neckermann, Reto Cueni and Bruno S. Frey, What is an Award Worth? An Econometric Assessment of the Impact of Awards on Employee Performance, May 2009

2658 Steven Brakman, Harry Garretsen and Charles van Marrewijk, Economic Geography within and between European Nations: The Role of Market Potential and Density across Space and Time, May 2009

2659 Giovanni Facchini and Cecilia Testa, Reforming Legislatures: Is one House better than two?, May 2009

2660 Carsten Kowalczyk and Raymond Riezman, Trade Agreements, May 2009

2661 Oliver Falck, Stephan Heblich and Elke Luedemann, Identity and Entrepreneurship, May 2009

2662 Christian Lessmann and Gunther Markwardt, One Size Fits All? Decentralization, Corruption, and the Monitoring of Bureaucrats, May 2009

2663 Felix Bierbrauer, On the Legitimacy of Coercion for the Financing of Public Goods, May 2009

2664 Alessandro Cigno, Agency in Family Policy: A Survey, May 2009

2665 Claudia M. Buch and Christian Pierdzioch, Low Skill but High Volatility?, May 2009

2666 Hendrik Jürges, Kerstin Schneider, Martin Senkbeil and Claus H. Carstensen, Assessment Drives Learning: The Effect of Central Exit Exams on Curricular Knowledge and Mathematical Literacy, June 2009

2667 Eric A. Hanushek and Ludger Woessmann, Schooling, Cognitive Skills, and the Latin American Growth Puzzle, June 2009

2668 Ourania Karakosta, Christos Kotsogiannis and Miguel-Angel Lopez-Garcia, Does Indirect Tax Harmonization Deliver Pareto Improvements in the Presence of Global Public Goods?, June 2009

2669 Aleksandra Riedl and Silvia Rocha-Akis, Testing the Tax Competition Theory: How Elastic are National Tax Bases in OECD Countries?, June 2009

2670 Dominique Demougin and Carsten Helm, Incentive Contracts and Efficient Unemployment Benefits, June 2009

2671 Guglielmo Maria Caporale and Luis A. Gil-Alana, Long Memory in US Real Output per Capita, June 2009 
2672 Jim Malley and Ulrich Woitek, Productivity Shocks and Aggregate Cycles in an Estimated Endogenous Growth Model, June 2009

2673 Vivek Ghosal, Business Strategy and Firm Reorganization under Changing Market Conditions, June 2009

2674 Francesco Menoncin and Paolo M. Panteghini, Retrospective Capital Gains Taxation in the Real World, June 2009

2675 Thomas Hemmelgarn and Gaëtan Nicodème, Tax Co-ordination in Europe: Assessing the First Years of the EU-Savings Taxation Directive, June 2009

2676 Oliver Himmler, The Effects of School Competition on Academic Achievement and Grading Standards, June 2009

2677 Rolf Golombek and Michael Hoel, International Cooperation on Climate-Friendly Technologies, June 2009

2678 Martin Cave and Matthew Corkery, Regulation and Barriers to Trade in Telecommunications Services in the European Union, June 2009

2679 Costas Arkolakis, A Unified Theory of Firm Selection and Growth, June 2009

2680 Michelle R. Garfinkel, Stergios Skaperdas and Constantinos Syropoulos, International Trade and Transnational Insecurity: How Comparative Advantage and Power are Jointly Determined, June 2009

2681 Marcelo Resende, Capital Structure and Regulation in U.S. Local Telephony: An Exploratory Econometric Study; June 2009

2682 Marc Gronwald and Janina Ketterer, Evaluating Emission Trading as a Policy Tool Evidence from Conditional Jump Models, June 2009

2683 Stephan O. Hornig, Horst Rottmann and Rüdiger Wapler, Information Asymmetry, Education Signals and the Case of Ethnic and Native Germans, June 2009

2684 Benoit Dostie and Rajshri Jayaraman, The Effect of Adversity on Process Innovations and Managerial Incentives, June 2009

2685 Peter Egger, Christian Keuschnigg and Hannes Winner, Incorporation and Taxation: Theory and Firm-level Evidence, June 2009

2686 Chrysovalantou Milliou and Emmanuel Petrakis, Timing of Technology Adoption and Product Market Competition, June 2009

2687 Hans Degryse, Frank de Jong and Jérémie Lefebvre, An Empirical Analysis of Legal Insider Trading in the Netherlands, June 2009

2688 Subhasish M. Chowdhury, Dan Kovenock and Roman M. Sheremeta, An Experimental Investigation of Colonel Blotto Games, June 2009 
2689 Alexander Chudik, M. Hashem Pesaran and Elisa Tosetti, Weak and Strong Cross Section Dependence and Estimation of Large Panels, June 2009

2690 Mohamed El Hedi Arouri and Christophe Rault, On the Influence of Oil Prices on Stock Markets: Evidence from Panel Analysis in GCC Countries, June 2009

2691 Lars P. Feld and Christoph A. Schaltegger, Political Stability and Fiscal Policy - Time Series Evidence for the Swiss Federal Level since 1849, June 2009

2692 Michael Funke and Marc Gronwald, A Convex Hull Approach to Counterfactual Analysis of Trade Openness and Growth, June 2009

2693 Patricia Funk and Christina Gathmann, Does Direct Democracy Reduce the Size of Government? New Evidence from Historical Data, 1890-2000, June 2009

2694 Kirsten Wandschneider and Nikolaus Wolf, Shooting on a Moving Target: Explaining European Bank Rates during the Interwar Period, June 2009

2695 J. Atsu Amegashie, Third-Party Intervention in Conflicts and the Indirect Samaritan's Dilemma, June 2009

2696 Enrico Spolaore and Romain Wacziarg, War and Relatedness, June 2009

2697 Steven Brakman, Charles van Marrewijk and Arjen van Witteloostuijn, Market Liberalization in the European Natural Gas Market - the Importance of Capacity Constraints and Efficiency Differences, July 2009

2698 Huifang Tian, John Whalley and Yuezhou Cai, Trade Sanctions, Financial Transfers and BRIC's Participation in Global Climate Change Negotiations, July 2009

2699 Axel Dreher and Justina A. V. Fischer, Government Decentralization as a Disincentive for Transnational Terror? An Empirical Analysis, July 2009

2700 Balázs Égert, Tomasz Koźluk and Douglas Sutherland, Infrastructure and Growth: Empirical Evidence, July 2009

2701 Felix Bierbrauer, Optimal Income Taxation and Public Goods Provision in a Large Economy with Aggregate Uncertainty, July 2009

2702 Marc Gronwald, Investigating the U.S. Oil-Macroeconomy Nexus using Rolling Impulse Responses, July 2009

2703 Ali Bayar and Bram Smeets, Government Deficits in the European Union: An Analysis of Entry and Exit Dynamics, July 2009

2704 Stergios Skaperdas, The Costs of Organized Violence: A Review of the Evidence, July 2009

2705 António Afonso and Christophe Rault, Spend-and-tax: A Panel Data Investigation for the EU, July 2009 
2706 Bruno S. Frey, Punishment - and beyond, July 2009

2707 Michael Melvin and Mark P. Taylor, The Crisis in the Foreign Exchange Market, July 2009

2708 Firouz Gahvari, Friedman Rule in a Model with Endogenous Growth and Cash-inadvance Constraint, July 2009

2709 Jon H. Fiva and Gisle James Natvik, Do Re-election Probabilities Influence Public Investment?, July 2009

2710 Jarko Fidrmuc and Iikka Korhonen, The Impact of the Global Financial Crisis on Business Cycles in Asian Emerging Economies, July 2009

2711 J. Atsu Amegashie, Incomplete Property Rights and Overinvestment, July 2009

2712 Frank R. Lichtenberg, Response to Baker and Fugh-Berman's Critique of my Paper, "Why has Longevity Increased more in some States than in others?", July 2009

2713 Hans Jarle Kind, Tore Nilssen and Lars Sørgard, Business Models for Media Firms: Does Competition Matter for how they Raise Revenue?, July 2009

2714 Beatrix Brügger, Rafael Lalive and Josef Zweimüller, Does Culture Affect Unemployment? Evidence from the Röstigraben, July 2009

2715 Oliver Falck, Michael Fritsch and Stephan Heblich, Bohemians, Human Capital, and Regional Economic Growth, July 2009

2716 Wladimir Raymond, Pierre Mohnen, Franz Palm and Sybrand Schim van der Loeff, Innovative Sales, R\&D and Total Innovation Expenditures: Panel Evidence on their Dynamics, July 2009

2717 Ben J. Heijdra and Jochen O. Mierau, Annuity Market Imperfection, Retirement and Economic Growth, July 2009

2718 Kai Carstensen, Oliver Hülsewig and Timo Wollmershäuser, Price Dispersion in the Euro Area: The Case of a Symmetric Oil Price Shock, July 2009

2719 Katri Kosonen and Gaëtan Nicodème, The Role of Fiscal Instruments in Environmental Policy, July 2009

2720 Guglielmo Maria Caporale, Luca Onorante and Paolo Paesani, Inflation and Inflation Uncertainty in the Euro Area, July 2009

2721 Thushyanthan Baskaran and Lars P. Feld, Fiscal Decentralization and Economic Growth in OECD Countries: Is there a Relationship?, July 2009

2722 Nadia Fiorino and Roberto Ricciuti, Interest Groups and Government Spending in Italy, 1876-1913, July 2009 